\title{
Effect of WBGT on body thermal responses for agricultural workers in Southern Rajasthan, India
}

\author{
S.K. SINGH, A.K. MEHTA AND S.S. MEENA
}

Received : 28.09.2016; Revised : 17.02.2017; Accepted : 03.03.2017

See end of the Paper for authors' affiliation

Correspondence to :

\section{S.K. SINGH}

Department of Agricultural Engineering (Farm Machinery and Power Engineering), College of Technology and Engineering, Maharana Pratap University of Agriculture and Technology, UDAIPUR (RAJASTHAN) INDIA
- ABSTRACT : Rajasthan state is in west region of India. Maximum temperatures rise sharply exceeding $45^{\circ} \mathrm{C}$ by the end of May and early June resulting in harsh summers in the state. Heat stress is a condition that is caused by worker over-exposure to the high temperature work environments often found in outdoor agriculture operations. Wet Bulb Globe Temperature (WBGT) is a measure of heat stress. Considering the range of temperatures prevalent in the Rajasthan state during the months of May and June, agricultural operations during these months and the associated heat stress on the agricultural workers, this study was designed to ascertain the effect of WBGT on body thermal responses of agricultural workers. Southern Rajasthan was selected to conduct this study. The study was conducted on 12 farm workers. Different WBGT of $28^{\circ} \mathrm{C}, 29^{\circ} \mathrm{C}, 30^{\circ} \mathrm{C}$, $31^{\circ} \mathrm{C}$ and $32^{\circ} \mathrm{C}$ were selected for this study. Thermal parameters included head, forehead and oral temperature. Forehead temperature was observed to decrease with an increase in WBGT. Heavy sweating was observed at high WBGT and this resulted in the decrease in skin and forehead temperature. Oral and head temperature was observed to increase with increase in WBGT. Since oral temperature is also considered to be the core temperature of body, it increased with increase in WBGT. Head absorbs the direct solar radiations and hence, its temperature increased with increase in WBGT.

- KEY WORDS : WBGT (Wet Bulb Globe Temperature), Heat stress, Thermal responses, Head temperature, Forehead temperature, Oral temperature, Core body temperature

- HOW TO CITE THIS PAPER : Singh, S.K., Mehta, A.K. and Meena, S.S. (2017). Effect of WBGT on body thermal responses for agricultural workers in Southern Rajasthan, India. Internat. J. Agric. Engg., 10(1) : 55-59, DOI: 10.15740/HAS/IJAE/10.1/55-59. 